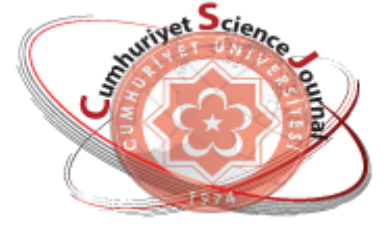

e-ISSN: $2587-246 X$

ISSN: 2587-2680

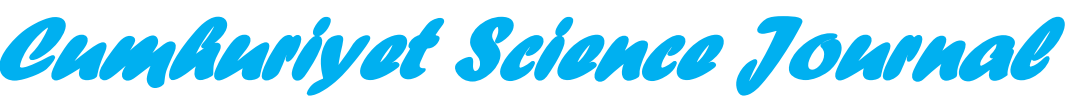

$\cos 7$

Cumhuriyet Sci. J., Vol.39-2(2018) 515-523

\title{
Optimization of Molding Unused New Sand Composition by Mixture Design Method
}

\author{
Mehmet KUL ${ }^{1 *}$, Kürşad O. OSKA $Y^{1}$, Erdem AKÇA ${ }^{1}$, Aytuğ E. ALSAN ${ }^{1}$, Bahadir KARACA ${ }^{2}$ \\ ${ }^{1}$ Cumhuriyet University, Department of Metallurgical and Materials Engineering, Sivas, TURKEY \\ ${ }^{2}$ ESTAS Camshaft Sivas, TURKEY
}

Received: 06.08.2017; Accepted: 07.05.2018

http://dx.doi.org/10.17776/csj.434264

\begin{abstract}
In this study, various parameters which affect the green strength, gas permeability and shear strength of unused casting sands were investigated in order to improve the quality of casting sands used in Estaş casting foundry. These parameters were chosen as water ratio $\%\left(\mathrm{X}_{1}\right)$, coal powder $\%\left(\mathrm{X}_{2}\right)$, active bentonite $\%\left(\mathrm{X}_{3}\right)$ and unused new sand $\%\left(\mathrm{X}_{4}\right)$. Mixture design (MD) method was used in the optimization studies. At the end of studies, the optimum $\mathrm{X}_{1}, \mathrm{X}_{2}, \mathrm{X}_{3}$ and $\mathrm{X}_{4}$ values, which maximize the compressive strength $\left(\mathrm{Y}_{1}\right)$, shear strength $\left(\mathrm{Y}_{2}\right)$ and gas permeability $\left(\mathrm{Y}_{3}\right)$ values, were determined as $3.50 \%, 6.00 \%, 6.66 \%$ and $83.08 \%$, respectively. $Y_{1}, Y_{2}$ and $Y_{3}$ values were determined as $12.7 \mathrm{~N} / \mathrm{Cm}^{2}, 4.0 \mathrm{~N} / \mathrm{cm}^{2}$ and $66 \mathrm{mmWS}$ at these optimum $\mathrm{X}_{1}, \mathrm{X}_{2}, \mathrm{X}_{3}$ and $\mathrm{X}_{4}$ values.
\end{abstract}

Keywords: Unused new sand, Optimization, Mixture Design.

\section{Karışım Tasarım Yöntemini ile Kullanılmamış Yeni Kum Bileşiminin Kalıplamasının Optimizasyonu}

Özet: Bu çalışmada; Estaş döküm fabrikasında kullanılan yeni döküm kumlarının kalitesinin artırılması için döküm kumunun yaş mukavemet, gaz geçirgenliği ve kesme mukavemetini etkileyen parametreler incelenmiştir. Bu parametreler \% nem oranı $\left(\mathrm{X}_{1}\right), \%$ kömür tozu $\left(\mathrm{X}_{2}\right)$, \% aktif bentonit $\left(\mathrm{X}_{3}\right)$ ve \% yeni kum miktarı $\left(\mathrm{X}_{4}\right)$ olarak seçilmiştir. Optimizasyon çalışmalarında karışım tasarım (KT) yöntemi kullanılmıştır. Yapılan çalışmalar sonucunda yeni kum kullanılarak hazırlanan döküm kumunun optimum kompozisyonu $\mathrm{X}_{1}$ $(\% 3,50), \mathrm{X}_{2}(\% 6,00), \mathrm{X}_{3}(\% 6,66), \mathrm{X}_{4}(\% 83,08)$ olarak belirlenmiştir. Bu optimum kompozisyonda hazırlanan kumun basma mukavemeti $\left(\mathrm{Y}_{1}\right) 12,7 \mathrm{~N} / \mathrm{cm}^{2}$, kesme mukavemeti $\left(\mathrm{Y}_{2}\right) 4,0 \mathrm{~N} / \mathrm{cm}^{2}$ ve gaz geçirgenliği $\left(\mathrm{Y}_{3}\right) 66$ mmWS olarak ölçülmüştür.

Anahtar Kelimeler: Yeni kum bileşimi, optimizasyon, karışım tasarım yöntemi.

\section{INTRODUCTION}

The main objective of the materials using for fabrication of sand mold in casting foundry is to give the net shape of casting cavity and keep this shape up to complete solidification of molten metal. The components required for mold are sand, coal powder and water. Sand provides refractory property while coal powder, which is naturally found in sand or added into the sand later, provides low surface roughness (better surface quality) of the cast parts due to inhibition of burning of sand. Besides, water is used for making the sand the suitable material for molding.

The quality of casting sand is determined by the properties of mold such as, compressive

\footnotetext{
* Corresponding author. Email address: kulmeh@gmail.com

http://dergipark.gov.tr/csj C2016 Faculty of Science, Cumhuriyet University
} 
strength, shear strength and gas permeability, which depend on the ratio (\%) of mold components. Green (compressive) strength means that the strength of mold after the addition of water into casting sand. The shape and size of the sand particles, the type and amount of binder (bentonite), humidity ratio are some factors that affect the green strength. Meanwhile, shear strength also depends on the same factors. In other words, the effects of these factors on green and shear strengths are very similar. Gas permeability is the capability of air, gas and vapor permeability in casting sand. Also, gas permeability depends on the shape and size of the sand particles, the amounts of binder and humidity[1, 3]. However, the most effective parameter for the properties of casting sand is the binder called as "bentonite" which results in binding of sand particles each other thanks to be activated by humidity. For example, both of bentonite $\%$ and humidity $\%$ should be increased in order to increase green strength, however, decrease in the gas permeability of sand should be taken into account at the same time [2].

In literature, suitable optimization methods together with experimental designs were carried out for recycling sand by taking into consideration of the inverse ratio between expected properties of casting sand and the components $\%$ in casting sand and optimum compositions for casting sand were arisen $[2,5$, $6]$. But there is not any study in the literature about new unused fresh mould sand. Experimental design is a statistical method used for determining the most suitable experiments in order to provide consistency with a specific mathematical model. Moreover, it is an effective way to ensure obtained results which are acceptable and objective results $[4,6,7]$. The compositions and process parameters of unused new fresh casting sand in foundry were optimized through Taguchi method in literature [5]. A formulation was computed to determine optimum values for process and interaction factors (humidity ratio, green strength, particle size, gas permeability, hardness of mold) by performing very few experiments in a previous work. As a result, it was reported that the casting defects decrease by $37.66 \%$ [5]. In other work, experimental approach was considered for all process parameters, which were bentonite \%, mixing time and compactability. As a result, bentonite ratio, mixing time and compactability were estimated as $9 \%, 11$ minutes and 45 , respectively. It was reported that these were optimum values in respect to maximizing green compressive strength and gas permeability together with required minimum value for green tensile strength as well [4].

In this study, it was aimed that increasing molding efficiency and also decreasing the cost of final machining of casting pieces through Mixture/D-Optimal method, which is used for reducing the number of experiments required for preparing casting sand. Comparison with previous optimization studies, the results obtained by Mixture/D-Optimal method could be used for all foundry factories. Besides, recycled sand using for several casting processes was preferred in previous works $[8,9]$. However, the unused new fresh sand, which was never used for any casting procedure, was preferred for the first time in this study in order to determine the casting sand composition with optimum values by Mixture/D-Optimal method.

For this purpose, the mathematical models including green compressive strength $\left(\mathrm{Y}_{1}\right)$, shear strength $\left(\mathrm{Y}_{2}\right)$ and gas permeability $\left(\mathrm{Y}_{3}\right)$ as a function of water ratio $\%\left(\mathrm{X}_{1}\right)$, coal powder $\%$ $\left(\mathrm{X}_{2}\right)$, active bentonite $\%\left(\mathrm{X}_{3}\right)$ and unused new sand $\%\left(\mathrm{X}_{4}\right)$ were estimated in this study. By using these models, $\mathrm{X}_{1}, \mathrm{X}_{2}, \mathrm{X}_{3}$ and $\mathrm{X}_{4}$ values that maximize $Y_{1}, Y_{2}$ and $Y_{3}$ values of casting sand were obtained.

\section{EXPERIMENTAL PROCEDURE}

\subsection{Materials and Method}

Technical information and ingredients of using raw materials in this study were shown in Table 
1. Experimental methods were carried out for several steps. Firstly, $5 \mathrm{~kg}$ of batches was used for each step in order to ensure homogenous mixing of casting sand. Batches were mixed for 3-4 minutes with constant rotational speed in laboratory type sand mixer. 5 gr of samples from mixed batches were taken place into infrared drying device in order to determine the humidity. Humidity value of sand should be close to that of defined in experimental design. $145 \mathrm{~g}$ of samples from batches were then taken place into the universal strength device and molded. After that, green strength and shear strength values were determined. $145 \mathrm{~g}$ of samples were also taken place into the measuring. The gas permeability values were also determined by using gas permeability device from $145 \mathrm{~g}$ of samples tested for $40-60$ seconds.

Table 1. Technical data and ingredients of raw materials.

\begin{tabular}{llllll}
\hline \multicolumn{1}{c}{ Silica sand } & \multicolumn{3}{c}{ Coal powder } & \multicolumn{2}{c}{ Bentonite } \\
\hline Particle Size (AFS) & 63.84 & Amount of Carbon(\%) & 61.22 & Humidity $(\%)$ & 81.00 \\
\hline Sintering temperature $\left({ }^{\circ} \mathrm{C}\right)$ & 1500 & Ash $(\%)$ & 23.10 & Montmorillonite $(\%)$ & 7.00 \\
LOI (\%) & 0.20 & Volatile matter $(\%)$ & 32.80 & Green compressive strength $\left(\mathrm{N} / \mathrm{cm}^{2}\right)$ & 0.25 \\
Clay (\%) & 0.20 & Sulphur $(\%)$ & 0.74 & Green tensile strength (N/ $\left.\mathrm{cm}^{2}\right)$ & 13.75 \\
Humidity $(\%)$ & 0.25 & Humidity $(\%)$ & 5.80 & Swelling index $(\mathrm{ml})$ & \\
\hline
\end{tabular}

\section{RESULTS and DISCUSSION}

Experimental steps and process conditions were carefully determined to ensure that the experiments could be carried out at optimum and homogenous experimental conditions. Therefore, optimization limit values were estimated by Mixture Design, which is a type of response surface methodology used for optimizing mixture, during our preliminary work. D-Optimal, which is one of sub-design option in Mixture Design, was preferred for preparing the casting sand procedure. On the other hand effects of process variables on the physical properties of casting sand together with interaction of process variables each other can be determined by statistical experimental design. Intervals for process variables determined in preliminary work were $(3.50<$ $\left.X_{1}<4.60\right),\left(4.50<X_{2}<6.00\right),\left(6.50<X_{3}<8.00\right)$ and $\left(81.40<X_{4}<85.50\right)$. Designed experiments by using these intervals were shown Table 2 . Casting sands were prepared based on the experimental design and then tested. Also, experimental strength and gas permeability results were compared with estimated ones in Table 2. The results obtained via mathematical model and experiments were found to be consistent each other. 
Table 2.Experimental sets and results obtained via D-Optimal Mixture Design Method.

\begin{tabular}{|c|c|c|c|c|c|c|c|c|c|c|}
\hline \multirow[b]{2}{*}{$\begin{array}{c}\# \\
\text { Experi } \\
\text { ment }\end{array}$} & \multicolumn{4}{|c|}{ Amounts of variables / \% } & \multicolumn{3}{|c|}{ Experimental Results } & \multicolumn{3}{|c|}{ Estimated Results } \\
\hline & $\begin{array}{c}\mathrm{X}_{1} \text { Humid } \\
\text { ity }\end{array}$ & $\begin{array}{c}\mathrm{X}_{2} \\
\text { Coal }\end{array}$ & $\begin{array}{c}\mathrm{X}_{3} \\
\text { Bentonite }\end{array}$ & $\begin{array}{c}\mathrm{X}_{4} \\
\text { New Sand }\end{array}$ & $\begin{array}{c}\text { Y }{ }_{1} \text { Compres } \\
\text { sive } \\
\text { Strength } \\
\left(\mathrm{N} / \mathrm{cm}^{2}\right)\end{array}$ & $\begin{array}{c}\mathrm{Y}_{2} \\
\text { Shear } \\
\text { Strength } \\
\left(\mathrm{N} / \mathrm{cm}^{2}\right)\end{array}$ & $\begin{array}{c}\mathrm{Y}_{3} \\
\text { Gas } \\
\text { Permeability } \\
(\mathrm{mmWS})\end{array}$ & $\begin{array}{c}\mathrm{Y}_{1} \\
\text { Comp. } \\
\text { Strength } \\
\left(\mathrm{N} / \mathrm{cm}^{2}\right)\end{array}$ & $\begin{array}{c}\mathrm{Y}_{2} \\
\text { Shear } \\
\text { Strength } \\
\left(\mathrm{N} / \mathrm{cm}^{2}\right)\end{array}$ & $\begin{array}{c}\mathrm{Y}_{3} \mathrm{Gas} \\
\text { Perm. } \\
(\mathrm{mmW} \\
\mathrm{S})\end{array}$ \\
\hline 1 & 3.77 & 5.62 & 6.87 & 83.72 & 11.1 & 3.5 & 62 & 10.95 & 3.53 & 61.6 \\
\hline 2 & 4.32 & 4.87 & 6.87 & 83.92 & 9.9 & 3.3 & 60 & 9.50 & 3.12 & 62.9 \\
\hline 3 & 3.50 & 5.25 & 8.00 & 83.25 & 13.3 & 4.3 & 58 & 13.33 & 4.34 & 57.1 \\
\hline 4 & 4.60 & 5.25 & 6.50 & 83.65 & 8.9 & 3.0 & 59 & 8.58 & 2.94 & 60 \\
\hline 5 & 4.60 & 5.25 & 7.25 & 82.90 & 10.4 & 3.4 & 55 & 10.35 & 3.3 & 57.2 \\
\hline 6 & 3.77 & 4.87 & 7.62 & 83.72 & 12.1 & 4.0 & 60 & 12.00 & 3.86 & 62.8 \\
\hline 7 & 4.60 & 4.50 & 8.00 & 82.90 & 11.8 & 3.9 & 59 & 11.38 & 3.87 & 59.2 \\
\hline 8 & 4.05 & 5.25 & 8.00 & 82.70 & 13.2 & 4.5 & 57 & 12.56 & 4.03 & 57.3 \\
\hline 9 & 4.05 & 6.00 & 6.50 & 83.45 & 10.4 & 3.4 & 59 & 10.17 & 3.35 & 62.4 \\
\hline 10 & 4.60 & 4.50 & 6.50 & 84.40 & 8.5 & 3.0 & 61 & 8.34 & 2.89 & 62 \\
\hline 11 & 3.50 & 4.50 & 6.50 & 85.50 & 8.8 & 3.0 & 64 & 9.58 & 3.14 & 64.8 \\
\hline 12 & 3.50 & 6.00 & 8.00 & 82.50 & 13.5 & 4.4 & 54 & 13.44 & 4.37 & 54.3 \\
\hline 13 & 3.50 & 5.25 & 6.50 & 84.75 & 10.2 & 3.3 & 62 & 10.38 & 3.35 & 64.1 \\
\hline 14 & 4.60 & 5.25 & 8.00 & 82.15 & 12.1 & 4.0 & 56 & 12.12 & 4.02 & 53.6 \\
\hline 15 & 4.05 & 6.00 & 7.25 & 82.70 & 12.5 & 3.8 & 58 & 11.66 & 3.68 & 58.1 \\
\hline 16 & 4.05 & 4.50 & 6.50 & 84.95 & 9.2 & 3.1 & 66 & 8.79 & 3.0 & 65.3 \\
\hline 17 & 3.50 & 6.00 & 7.25 & 83.25 & 12.3 & 3.9 & 61 & 12.48 & 4.02 & 57.6 \\
\hline 18 & 4.32 & 5.62 & 7.62 & 82.42 & 11.7 & 3.7 & 55 & 11.81 & 3.73 & 56.3 \\
\hline 19 & 4.05 & 4.50 & 8.00 & 83.45 & 11.9 & 3.8 & 63 & 12.30 & 3.99 & 64.4 \\
\hline 20 & 3.77 & 5.62 & 7.62 & 82.97 & 12.3 & 3.8 & 55 & 12.34 & 3.94 & 57.3 \\
\hline 21 & 4.60 & 6.00 & 7.25 & 82.15 & 11.3 & 3.6 & 55 & 11.18 & 3.5 & 54.7 \\
\hline 22 & 3.50 & 5.25 & 7.25 & 84.00 & 11.9 & 3.6 & 60 & 11.86 & 3.86 & 61 \\
\hline 23 & 3.50 & 4.50 & 7.25 & 84.75 & 13.3 & 4.5 & 65 & 11.57 & 3.79 & 67.2 \\
\hline 24 & 4.32 & 4.87 & 7.62 & 83.17 & 11.4 & 3.8 & 61 & 11.17 & 3.59 & 60.5 \\
\hline 25 & 3.50 & 4.50 & 8.00 & 84.00 & 12.8 & 4.2 & 68 & 13.57 & 4.41 & 65.8 \\
\hline 26 & 3.50 & 6.00 & 6.50 & 84.00 & 11.6 & 3.9 & 63 & 11.52 & 3.65 & 63.2 \\
\hline 27 & 4.60 & 6.00 & 8.00 & 81.40 & 13.2 & 4.1 & 54 & 13.20 & 4.27 & 53.9 \\
\hline 28 & 4.60 & 6.00 & 6.50 & 82.90 & 9.1 & 3.0 & 59 & 9.17 & 3.08 & 57.8 \\
\hline 29 & 4.05 & 4.50 & 7.25 & 84.20 & 10.2 & 3.1 & 68 & 10.55 & 3.41 & 66.8 \\
\hline 30 & 4.05 & 6.00 & 8.00 & 81.95 & 12.6 & 4.2 & 56 & 13.15 & 4.17 & 56.2 \\
\hline 31 & 4.32 & 5.62 & 6.87 & 83.17 & 9.1 & 3.1 & 62 & 10.09 & 3.25 & 59.6 \\
\hline 32 & 4.60 & 4.50 & 7.25 & 83.65 & 9.1 & 3.0 & 64 & 9.86 & 3.2 & 62.5 \\
\hline 33 & 3.77 & 4.87 & 6.87 & 84.47 & 10.2 & 3.1 & 71 & 10.29 & 3.36 & 64.9 \\
\hline 34 & 4.05 & 5.25 & 6.50 & 84.20 & 8.9 & 3.0 & 68 & 9.31 & 3.13 & 63.9 \\
\hline
\end{tabular}

\subsection{Statistical Analysis of Experimental Data:}

Equations predicated by mathematical models defined green compressive strength $\left(\mathrm{Y}_{1}\right)$, shear strength $\left(\mathrm{Y}_{2}\right)$ and gas permeability $\left(\mathrm{Y}_{3}\right)$ values were shown together with and their coefficient of determination $\left(\mathrm{R}^{2}\right)$ values in Table 3. These equations were used for obtaining estimated results shown in Table $2 . \mathrm{R}^{2}$ is a statistical measure of how close the data are to the fitted regression line. It is also known as the coefficient of determination, or the coefficient of multiple determination for multiple regression. The definition of $\mathrm{R}^{2}$ is fairly straight-forward; it is the percentage of the response variable variation that is explained by a linear model as shown in Figure $1 . \mathrm{R}^{2}$ in the Table 3 indicates that a model fits the response data well, in other words, variations between the experimentally observed values and model's predicted values are small and unbiased. The higher the $\mathrm{R}^{2}$ values in this study meant that there was a good correlation between independent input variables of obtained mathematical models and output response.

Plotting responses simulated by mathematical models versus experimentally observed ones were graphically illustrated in Figure 1.The fitted values were found to be close to the observed ones since the regression models accounted for $89.54 \%, 81.48 \%$ and $76.82 \%$ for $\mathrm{Y}_{1}, \mathrm{Y}_{2}$ and $\mathrm{Y}_{3}$, respectively. That is, there 
was a good correlation between results obtained via mathematical model and the real ones.

Table 3. Simulated Mathematical Models.

\begin{tabular}{|c|c|}
\hline Mathematical Models & $\mathrm{R}^{2}$ \\
\hline$Y_{1}=91.40 X_{1}+62.93 X_{2}+26.61 X_{3}-1.69 X_{4}-9.57 X_{1} X_{2}-6.70 X_{1} X_{3}$ & $89.54 \%$ \\
\hline$-0.55 \mathrm{X}_{1} \mathrm{X}_{4}-5.55 \mathrm{X}_{2} \mathrm{X}_{3}-0.29 \mathrm{X}_{2} \mathrm{X}_{4}+1.23 \mathrm{X}_{1} \mathrm{X}_{2} \mathrm{X}_{3}$ & $81.48 \%$ \\
\hline \multicolumn{2}{|l|}{$Y_{2}=-156.68 X_{1}+16.03 X_{2}-84.17 X_{3}-1.36 X_{4}-0.32 X_{1} X_{2}$} \\
\hline$+25.59 X_{1} X_{3}+1.98 X_{1} X_{4}-0.30 X_{2} X_{3}-0.085 X_{3} X_{4}+1.11 X_{3} X_{4}-0.31 X_{1} X_{3} X_{4}$ & $76.82 \%$ \\
\hline \multicolumn{2}{|l|}{$Y_{3}=-478.0 X_{1}-1802.7 X_{2}-1499.16 X_{3}-22.30 X_{4}+4.83 X_{1} X_{2}$} \\
\hline$+7.41 X_{1} X_{3}+6.30 X_{1} X_{4}+292.35 X_{2} X_{3}+23.22 X_{3} X_{4}+19.38 X_{3} X_{4}-3.55 X_{2} X_{3} X_{4}$ & \\
\hline
\end{tabular}
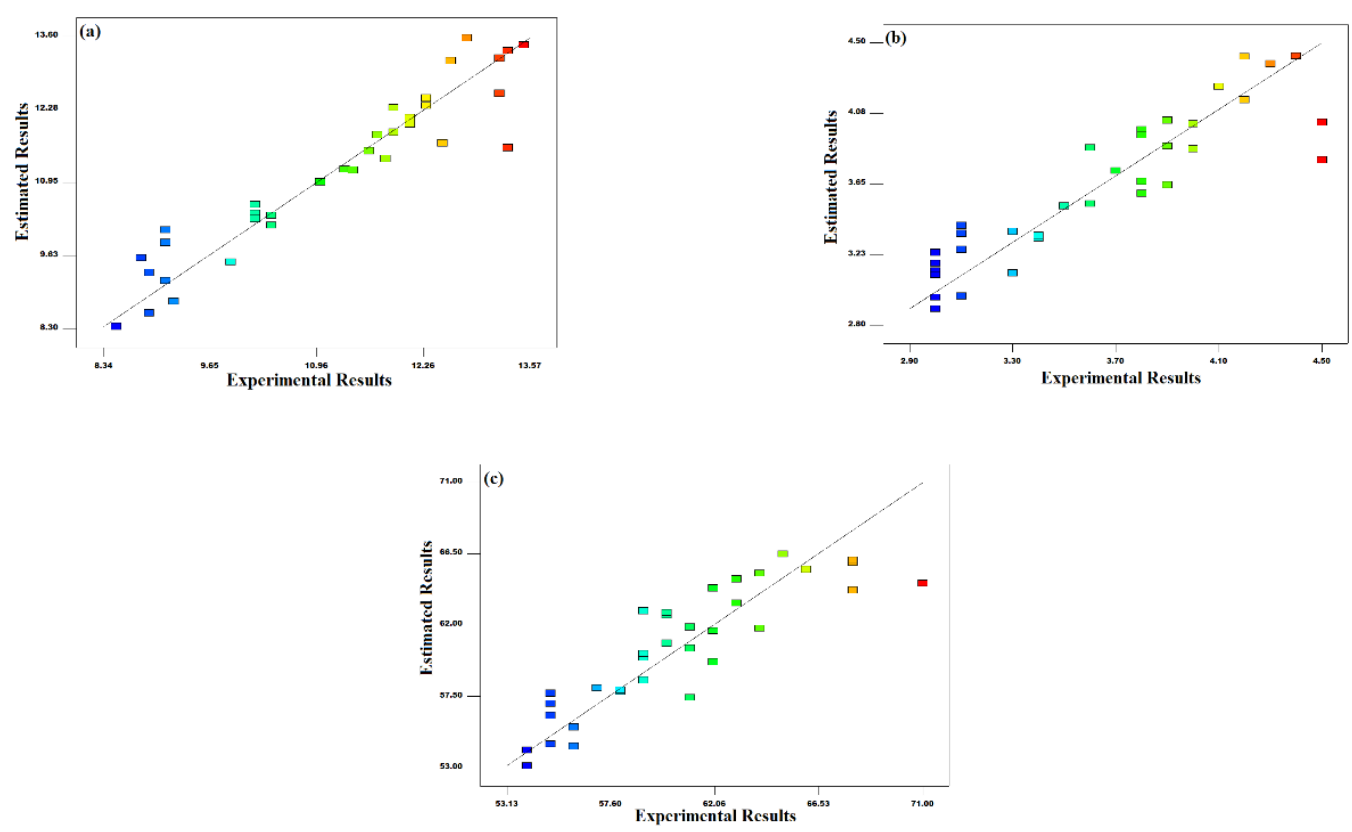

Figure 1. The comparison of estimated and observed responses for (a) $Y_{1}$,(b) $Y_{2}$ and (c) $Y_{3}$.

Variance analysis (ANOVA) was used for determining simple and interactive effects of experimental parameters on responses. ANOVA analysis for $Y_{1}, Y_{2}$ and $Y_{3}$ values were shown in Tables 4-6.

$\mathrm{P}$ value is a statistical measure that determines whether or not a parameter or its interaction was effective on the response. If $\mathrm{P}$ value is lower than 0.05 ( $5 \%$ of probability value) by considering $95 \%$ of the confidence bounds, the variables of experiment have statistically meaningful effect on the results [7]. For instance, $\mathrm{P}$-value for $\mathrm{Y}_{1}$ was calculated as 0.0001 based on the $F$ test value was 22.8338 . P-value was lower than 0.05 exhibited that the mathematical model for $\mathrm{Y}_{1}$ including percentages variables $\left(\mathrm{X}_{1} /\right.$ Humidity, $\mathrm{X}_{2} /$ Coal, $\mathrm{X}_{3}$ /Bentonite, $\quad \mathrm{X}_{4} /$ Sand $) \quad$ explained $\quad \mathrm{Y}_{1}$ (compressive strength) response very well.

In addition, $\mathrm{R}^{2}$ and adj. (adjusted) $\mathrm{R}^{2}$ values were close to 1 meant that there was a good agreement with independent variables in mathematical model and response. $\mathrm{R}^{2}$ and adj. 
$\mathrm{R}^{2}$ values for $\mathrm{Y}_{1}$ were, respectively, 0.89543 and 0.8562 depicted that clarity of experimental process was $85.62 \%$. The similar situation was valid for $\mathrm{Y}_{2}$ and $\mathrm{Y}_{3}$ variables as well. However, the representability of mathematical model for $\mathrm{Y}_{3} /$ Gas permeability was observed to be lower

Table 4. ANOVA results for $\mathrm{Y}_{1}$ (Compressive Strength). compared with that of $\mathrm{Y}_{1}$ or $\mathrm{Y}_{2}$ due to lower $\mathrm{R}^{2}=0.76826$ of $\mathrm{Y}_{3}$.

\begin{tabular}{ccccccc}
\hline Source & SS & df & MSS & F Value & Prob> F & \multirow{2}{*}{ significant } \\
Model & 72.4403 & 9 & 8.04892 & 22.8338 & $<0.0001$ & \\
Linear Mixture & 70.1914 & 3 & 23.3971 & 66.3747 & $<0.0001$ & \\
$\mathrm{X}_{1} \mathrm{X}_{2}$ & 0.75017 & 1 & 0.75017 & 2.12813 & 0.1576 & \\
$\mathrm{X}_{1} \mathrm{X}_{3}$ & 0.45225 & 1 & 0.45225 & 1.28296 & 0.2685 & \\
$\mathrm{X}_{1} \mathrm{X}_{4}$ & 0.1894 & 1 & 0.1894 & 0.53731 & 0.4706 & \\
$\mathrm{X}_{2} \mathrm{X}_{3}$ & 1.33099 & 1 & 1.33099 & 3.77585 & 0.0638 & \\
$\mathrm{X}_{2} \mathrm{X}_{4}$ & 0.1894 & 1 & 0.1894 & 0.53731 & 0.4706 & \\
\hline Residual & 8.46002 & 24 & 0.3525 & & & \\
Cor. Total & 80.9003 & 33 & & & & \\
$\mathrm{R}^{2}$ & 0.89543 & & & & \\
Adj. $\mathrm{R}^{2}$ & 0.85621 & & & & \\
Pred. $\mathrm{R}^{2}$ & 0.75158 & & & &
\end{tabular}

Table 5. ANOVA results for $\mathrm{Y}_{2}$ (Shear Strength).

\begin{tabular}{ccccccc}
\hline Source & SS & df & MSS & F Value & Prob $>$ F & \multirow{2}{*}{ significant } \\
Model & 6.42567 & 8 & 0.80321 & 13.7488 & $<0.0001$ & \\
Linear Mixture & 6.14838 & 3 & 2.04946 & 35.0812 & $<0.0001$ & \\
$\mathrm{X}_{1} \mathrm{X}_{2}$ & 0.11779 & 1 & 0.11779 & 2.01626 & 0.1680 & \\
$\mathrm{X}_{1} \mathrm{X}_{4}$ & 0.09975 & 1 & 0.09975 & 1.70746 & 0.2032 & \\
$\mathrm{X}_{2} \mathrm{X}_{3}$ & 0.107 & 1 & 0.107 & 1.83149 & 0.1881 & \\
$\mathrm{X}_{2} \mathrm{X}_{4}$ & 0.01361 & 1 & 0.01361 & 0.23295 & 0.6335 & \\
$\mathrm{X}_{1} \mathrm{X}_{3} \mathrm{X}_{4}$ & 0.19172 & 1 & 0.19172 & 3.28167 & 0.0821 & \\
\hline Residual & 1.46051 & 25 & 0.05842 & & & \\
Cor. Total & 7.88618 & 33 & & & & \\
$\mathrm{R}^{2}$ & 0.8148 & & & & & \\
Adj. $\mathrm{R}^{2}$ & 0.75554 & & & & & \\
Pred. $\mathrm{R}^{2}$ & 0.64764 & & & & & \\
Adeq. Precision & 12.2218 & & & &
\end{tabular}


Table 6. ANOVA results for $\mathrm{Y}_{3}$ (Gas Permeability).

\begin{tabular}{ccccccc}
\hline Source & SS & df & MSS & F Value & Prob> F & \multirow{2}{*}{ significant } \\
Model & 502.802 & 8 & 62.8502 & 10.3598 & $<0.0001$ & \\
Linear Mixture & 418.6 & 3 & 139.533 & 22.9997 & $<0.0001$ & \\
$\mathrm{X}_{1} \mathrm{X}_{2}$ & 14.3178 & 1 & 14.3178 & 2.36004 & 0.1370 \\
$\mathrm{X}_{1} \mathrm{X}_{3}$ & 18.2688 & 1 & 18.2688 & 3.0113 & 0.0950 \\
$\mathrm{X}_{1} \mathrm{X}_{4}$ & 24.9796 & 1 & 24.9796 & 4.11746 & 0.0532 \\
$\mathrm{X}_{3} \mathrm{X}_{4}$ & 14.5269 & 1 & 14.5269 & 2.39452 & 0.1343 \\
$\mathrm{X}_{2} \mathrm{X}_{3} \mathrm{X}_{4}$ & 41.3765 & 1 & 41.3765 & 6.8202 & 0.0150 \\
\hline Residual & 151.669 & 25 & 6.06675 & & & \\
Cor Total & 654.471 & 33 & & & & \\
$\mathrm{R}^{2}$ & 0.76826 & & & & \\
Adj. $\mathrm{R}^{2}$ & 0.6941 & & & \\
Pred. $\mathrm{R}^{2}$ & 0.61931 & & & \\
Adeq. Precision & 10.5332 & & &
\end{tabular}

\subsection{Effects of Experimental Variables on the Physical Properties of Casting Sand}

Effects of percentages of humidity, bentonite and coal on the compressive strength were shown in Figure 2. Compressive strength increased clearly by increasing amount of bentonite together with decreasing humidity level. Increase in compressive strength was explained that binding of sand particles each other due to active bentonite. In addition, compressive strength decreased when the humidity was higher than $3.5 \%$, which was upper limit for activating of bentonite. The binding capability of bentonite got worse due the higher the humidity. On the other hand, the amount of coal was found to be no influence on the compressive strength.

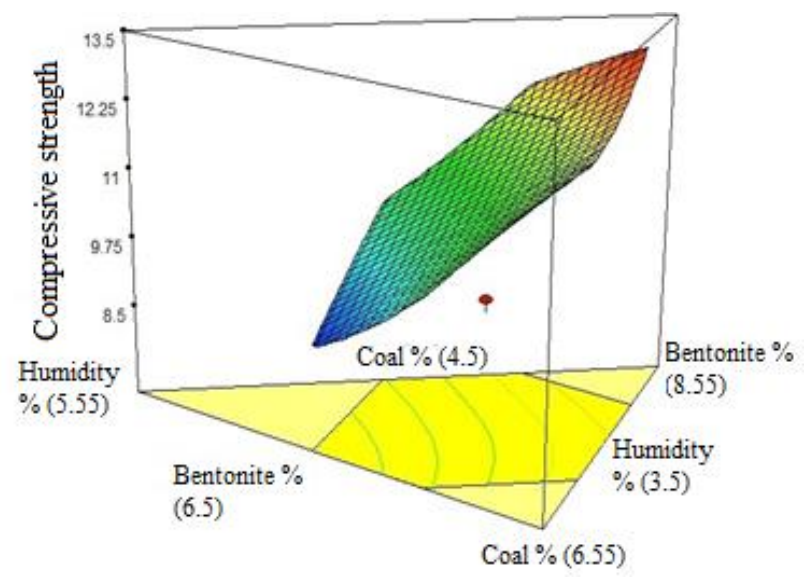

Figure 2. 3D response-surface graph for the effects of variables on the compressive strength.

Effects of percentages of humidity, bentonite and coal on the gas permeability were shown in Figure 4 . When humidity level was at minimum as seen in Figure 4, gas permeability was observed to be minimum as well. Besides, gas permeability reached to peak value with increasing the humidity up to a certain level, however, decreasing trend in gas permeability was observed due to further increase in humidity level. The lower the humidity ratio gave rise to decreasing the activation of 
bentonite, therefore, surfaces of sand particles were not wrapped well due to insufficient water ratio and also inactive bentonite occupied the pores encapsulating between sand particles. On the other hands, gas permeability decreased because residual water which was not absorbed by the bentonite due to higher water ratio occupied the pores encapsulating between sand particles as well. In addition, gas permeability decreased with increasing the amount of the coal since pores between sand particles was filled by the coal due to its finer particle size.

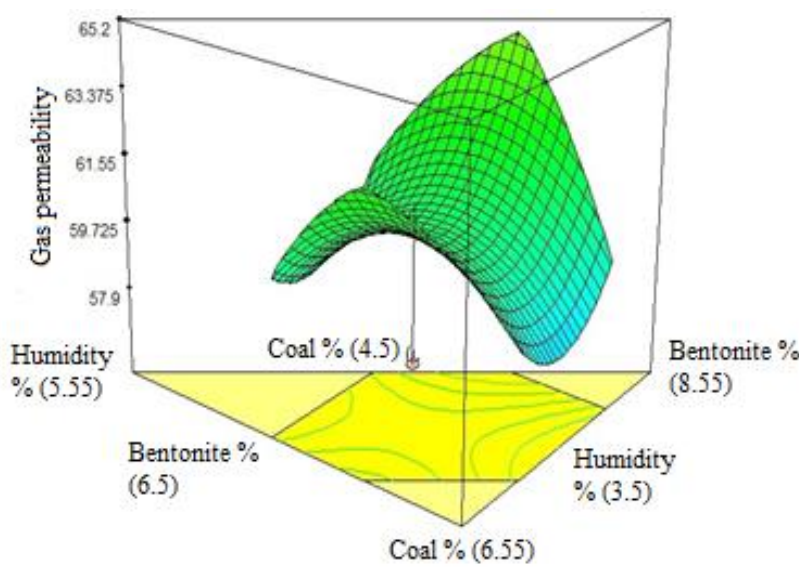

permeability were determined via Mini Tab software. The results of validation experiments done at optimum conditions were shown in Table 7. The experimental and simulated values were found to be consistent each other. It proved that the model revealed meaningful results at determined intervals for water ratio \% $\left(\mathrm{X}_{1}\right)$, coal powder $\%\left(\mathrm{X}_{2}\right)$, active bentonite $\%$ $\left(\mathrm{X}_{3}\right)$ and unused new sand $\%\left(\mathrm{X}_{4}\right)$. In other words, how compressive strength, shear strength and gas permeability of casting sand could be varied by using these models.

Figure 4. 3D response-surface graph for the effects of variables on the gas permeability.

Optimum conditions that maximize compressive strength, shear strength and gas

Table 7. Estimated and experimental results for optimum values obtained by Mixture Design Method.

\begin{tabular}{cccccccccc}
\hline $\begin{array}{c}\text { Humidity } \\
\%\end{array}$ & $\begin{array}{c}\text { Coal } \\
\%\end{array}$ & $\begin{array}{c}\text { Bentonite } \\
\%\end{array}$ & $\begin{array}{c}\text { Sand } \\
\%\end{array}$ & $\begin{array}{c}\text { Comp. } \\
\text { Strength( } \\
\left.\mathrm{N} / \mathrm{cm}^{2}\right)\end{array}$ & $\begin{array}{c}\text { Shear } \\
\text { Strength( } \\
\left.\mathrm{N} / \mathrm{cm}^{2}\right)\end{array}$ & $\begin{array}{c}\text { Gas } \\
\text { Perm. } \\
(\mathrm{mmWS})\end{array}$ & $\begin{array}{c}\text { Estimated } \\
\text { Comp. } \\
\text { Strength }\end{array}$ & $\begin{array}{c}\text { Estimated } \\
\text { Shear } \\
\text { Strength }\end{array}$ & $\begin{array}{c}\text { Estimated } \\
\text { Gas } \\
\text { Perm. }\end{array}$ \\
\hline 3.5 & 4.5 & 8.0 & 84.0 & 12.7 & 4.0 & 66 & 13.5 & 4.4 & 65 \\
3.5 & 6.0 & 6.6 & 83.8 & 11.2 & 3.5 & 63 & 11.6 & 3.7 & 62 \\
\hline
\end{tabular}

\section{CONCLUSION}

In this study, the physical properties of casting sand were enhanced by changing the amounts of the components in casting sand used in foundry factory. In this respect, how the amounts of sand, bentonite, coal and humidity affected compressive strength, shear strength and gas permeability of casting sand were determined. Optimization studies for new (unused, fresh) sand were carried out through experiments and analysis compatible with experimental designs. The results that obtained were concluded below:

1. Literature investigations were carried out for the optimization studies for new sand in order to determine upper and lower bounds of variables forming casting sand. The intervals of variables for new sand were determined as $\left(3.50<\mathrm{X}_{1}<4.60\right)$, 
$\left(4.50<\mathrm{X}_{2}<6.00\right)$,

$\left(6.50<\mathrm{X}_{3}<8.00\right)$,

$\left(81.40<\mathrm{X}_{4}<85.50\right)$.

2. Various tests for sand were done based on the experimental designs established by using intervals of variables. As a result of experimental studies, the composition of new sand was determined as $3.5 \%$ for $\mathrm{X}_{1}$, $6 \%$ for $\mathrm{X}_{2}, 6.66 \%$ for $\mathrm{X}_{3}, 83.08 \%$ for $\mathrm{X}_{4}$, respectively. Compressive strength, shear strength and gas permeability of casting sand were found to be, respectively, 12.7 $\mathrm{N} / \mathrm{cm}^{2}, 4 \mathrm{~N} / \mathrm{cm}^{2}$ and $66 \mathrm{mmWS}$ at the optimum conditions. Furthermore, it was observed that efficiency of casting sand increased in ESTAŞ Inc. Obtained experimental results were adequate and acceptable for industrial usage according to literature arguments.

3. The consistency in the results of regression and surface graphs in ANOVA analysis indicated that the method we used in this study was a promising method for similar works due to reliability.

\section{AKNOWLEDGEMENT}

This work was supported by The Scientific and Technological Research Council of Turkey (TÜBITAK) [Grant Number: 1139B411502706]. In addition, the authors thank to ESTAŞ Eksantirik San. ve Tic. A.Ş. where experimental studies were carried out.

\section{REFERENCES}

[1]. Aran A., Döküm Teknolojisi İmal Usulleri Ders Notları, İTÜ Makine Fakültesi, İstanbul, 2007.

[2]. Ramana M., Rau S., Prasad N., Parametric Optimization of Green Sand Moulding Process Based on Wet Tensile Strength, Int. J. of Eng. Res. \& Tech., 212 (2013) 2544-2548.

[3]. Özel A., Döküm Prensipleri ve Teknolojisi, 2. Bölüm, Sakarya Üniversitesi, 2013.

[4]. Erdoğan F., Yükseltilmiş D-Optimal Dizayn Yöntemi Kullanılarak
Mühendislik Dizaynlarında Etkinliğin Geliştirilmesi: 'Sentetik Jet' Dizayn Optimizasyon Çalışması, HHO Havacılık ve Uzay Teknolojileri Enstitüsü, Uzay Bilimleri Anabilim Dalı, İstanbul, 2007.

[5]. Upadhye R.A., Keswani I.P., Optimization of Sand Casting Process Parameter Using Taguchi Method in Foundry, Int. J. of Eng. Res. \& Tech., 1-7 (2012) 1-9.

[6]. Kumar M.S., Prakash J.M., Optimization of Casting Process Parameters Using Taguchi Analysis, Int. J. of Mech. Eng. and Res., 5-1 (2015) 1-3.

[7]. Kul M., Oskay K.O., Şimşir M., Sübütay H., Kirgezen H., Optimization of Selective Leaching of $\mathrm{Zn}$ from Electric Arc Furnace Steelmaking Dust Using Response Surface Methodology, Trans. Nonferrous Met. Soc. China., 25 (2015) 2753-2762.

[8]. Saikaew C. and Wiengwiset S., Optimization of Molding Sand Composition for Quality Improvement of Iron Castings, Appl. Clay. Sci., 67-68 (2012) 26-31.

[9]. Shahria S., Optimization of Molding Sand Composition for Casting Al Alloy, Int. J. of Mech. Eng. and Application., 53 (2017) 155-161. 